\title{
PERAN SPIRITUALITAS DALAM MENINGKATKAN RESILIENSI PADA RESIDEN NARKOBA
}

\author{
Diky Permana \\ Universitas Islam Negeri Sunan Gunung Djati Bandung \\ Jl. AH. Nasution No 105, Cibiru, Kota Bandung, Jawa Barat, Indonesia \\ E-mail: dikypermana66666@gmail.com
}

\begin{abstract}
This article was written based on research on the Role of Spirituality in Increasing Resilience in Resident Drugs at Pondok Pesantren Inabah XX Tasikmalaya. This study used qualitative descriptive method. The approach is psychological-spiritual. The point of the argument from this study, to know the extent to which the role of spirituality can affect the level of resilience in drug residents in following the spiritual-based rehabilitation. From this study it was found that drug residents were able to increase resilience when attending spiritual-based rehabilitation.
\end{abstract}

KEYWORDS:

Spirituality; resilience; resident drugs

\begin{abstract}
ABSTRAK
Artikel ini ditulis berdasarkan penelitian tentang Peran Spiritualitas Dalam Meningkatkan Resiliensi Pada Residen Narkoba di Pondok Pesantren Inabah XX Tasikmalaya. Kajian ini menggunakan metode deskriptif kualitatif. Adapun pendekatannya adalah psikologis-spiritual. Pokok argumentasi dari kajian ini, mengetahui sejauh mana peran spiritualitas dapat mempengaruhi tingkat resiliensi pada residen narkoba dalam mengikuti kegiatan rehabilitasi berbasis spiritual . Dari kajian ini ditemukan bahwa residen narkoba mampu meningkatkan resiliensi ketika mengikuti kegiatan rehabilitasi berbasis spiritual.
\end{abstract}

\section{KATA KUNCI:}

Spiritaulitas;reseliensi;residen narkoba.

DOI: https://doi.org/10.15575/saq.v2i2.2972

\section{A. PENDAHULUAN}

Kasus penyalahgunaan narkoba dalam tahun terakhir ini menimbulkan kecemasan bagi seluruh bangsa terutama Bangsa Indonesia. Bagaimana tidak, seiring berkembangnya ilmu pengetahuan dan teknologi, narkobapun mengalami perkembangan yang sama. Berdasarkan informasi dari Badan Narkotika Nasional (BNN) Di tahun 2017 selama bulan januari hingga juni tercatat ada 423 Kasus Narkoba, 
597 menjadi tersangka diantaranya 592 dari Warga Negara Indonesia (WNI) dan 5 orang lainya berasal dari Warga Negara Asing (WNA). ${ }^{1}$ Meskipun narkoba sangat diperlukan dalam pengobatan dan pelayanan kesehatan. Namun, bila disalah gunakan maka dampaknya sangat berbahaya bagi masa depan Bangsa Indonesia, terlebih jika disertai dengan peredaran gelap narkoba. ${ }^{2}$

Dampak yang ditimbulkan narkoba pada pecandu sangat berbahaya, maka dari itu perlu diadakanya proses rehabilitasi narkoba agar korban penyalahgunaan narkoba mempunyai kesempatan untuk berjuang kembali dalam menjalani hidup yang sehat tanpa penyalahgunaan narkoba. Oleh sebab itu tujuan pemulihan haruslah melibatkan aspek fisik, psikologis, sosial, agama dan spiritual.

Menurut konselor adiksi yang ada dirumah damping, permasalahan lain muncul ketika para residen narkoba ini menghadapi dua tantangan terbesar yaitu Relapse dan stigma negatif dari masyarakat. ${ }^{3}$ Masalah ini tentu menjadi hal yang amat penting bagi residen narkoba. Menurut kamus narkoba (BNN, 2006) relapse adalah mantan pengguna narkoba yang sempat "bersih" namun kembali mengkonsumsi narkoba. Fenomena ini sering terjadi karena selama apapun mantan pecandu narkoba berhenti menyalahgunakan narkoba, potensi relapse tetaplah tinggi. ${ }^{4}$ Disisi lain stigma negatif masyarakat merupakan ujian yang harus dihadapi oleh mantan pecandu narkoba, karena jika residen tidak kuat dalam menghadapi tekanan dalam hidupnya, kemungkinan besar akan mengalami

\footnotetext{
${ }^{1}$ Budi Waseso, Presentase Korban Penyalahgunaan Narkoba Tahun 2017, TV One, 12 Juni 2017 pukul 16:39 .

${ }^{2}$ Mardani, Penyalahgunaan Narkoba ( Dalam Prespektif Hukum Islam Dan Hukum Pidana Nasional) (Jakarta: PT. Raja Grafindo Persada, 2008), 11 .

${ }^{3}$ Muhammad Ikhsan (Konselor adiksi), wawancara oleh Diky Permana, Rumah Damping, Tanggal 7 November 2017
}

gangguan emosi atau bahkan hilangnya kepercayaan diri untuk sembuh.

Dalam ilmu psikologi, seseorang yang sedang menghadapi tekanan dan kemalangan hidup serta mampu menghadapinya dengan mantal yang kuat disebut dengan Resiliensi. Sagor memaparkan bahwa yang dimaksud dengan resiliensi adalah kumpulan atribut yang ada pada seorang individu dengan kekuatan dan ketabahan untuk menghadapi hambatan besar yang mengikat kehidupanya. ${ }^{5}$ Menurut Reivich dan Shatte, ada tujuh kemampuan yang membentuk resiliensi, yaitu regulasi emosi, pengendalian impuls, optimisme, empati, analisis penyebab masalah, efikasi diri, dan reaching out. Namun hampir tidak ada satupun individu yang secara keseluruhan memiliki tujuh kemampuan tersebut dengan baik apalagi untuk orang-orang khusus seperti residen narkoba. ${ }^{6}$

Maka dari itu pada dasarnya hal-hal yang mampu membentuk resilensi masih bersifat umum, mengapa? karena penelitian tentang resilensi hanya memaparkan bagaimana membentuk resilensi dengan tujuh kemampuan tersebut tanpa menjelaskan secara detail bagaimana ketujuh kemampuan tersebut dapat dilatih dalam kehidupan sehari-hari. Maka, ketika manusia sedang menghadapi sebuah masalah yang amat rumit dan mengalami tekanan dalam hidupnya, hal yang harus diperhatikan bukan hanya mengenai masalah psikologisnya tetapi juha kemampuan spiritualitas berperan penting. Tanpa adanya spiritualitas dan dalam diri manusia, maka hidupnya akan terasa hampa dan kosong, mereka akan mengalami

\footnotetext{
${ }^{4}$ BNN, Kamus Narkoba Istilah-Istilah Narkoba Dan Bahaya Penyalahgunaannya (Jakarta: Badan Narkotika Nasional Republik Indonesia, 2006), 13.

${ }^{5}$ Hamid Patalima, Resiliensi Anak Usia Dini (Bandung: Alfabeta, 2015), 53.

${ }^{6}$ A Reivich, K \& Shatte, The Resilience Factor: 7 Keys to Finding Your Inner Strength and Overcoming Life's Hurdles (New York: Broadway Books, 2002), 33.
} 
keterpurukan saat menghadapi masalah yang menekan psikologisnya, dan yang lebih fatal lagi,manusia akan kehilangan makna hidup.

Spiritualitas merupakan kebangkitan atau pencerahan diri dalam mencapai tujuan dan makna hidup selain itu spiritualitas juga merupakan bagian esensial dari keseluruhan kesehatan dan kesejahteraan seseorang. Berbeda dengan Religiusitas, religiusitas merupakan praktik dari prilaku tertentu yang dihubungkan dengan kepercayaan yang dinyatakan oleh institusi tertentu dan dianut oleh anggota-anggotanya. Maka dari itu dalam agama memiliki aspek iman, komunitas dan kode etik. ${ }^{7}$ Keterkaitan antara spiritualitas dan religiusitas terletak pada manfaat yang lebih integral. Contohnya saja dalam ibadah kepada Allah SWT berupa sholat. Sholat lima waktu merupakan kewajiban bagi seluruh umat muslim, karena dengan sholat menunjukan kepatuhan terhadap perintah Allah, itulah nilai religiusitasnya. Namun, disisi lain sholat merupakan sebuah terapi spiritual dimana seseorang mampu melatih kefokusan dan pada akhirnya timbulah ketenangan hati karena merasakan kehadiran-NYA. Sehingga pada aplikatifnya timbulah akhlak yang baik pada diri dan sesamanya, disitulah spirit sedang bekerja. Maka dari itu seharusnya spiritualitas dan religiusitas tidak dapat dipisahkan dan menjadi satu kesatuan terutama bagi kaum Sufi (pengikut ajaran tasawuf).Dari penjelasan diatas, spiritulitas ternyata berperan penting dalam membentuk pribadi manusia, sehingga manusia mampu memaknai hidup serta bijaksana dalam menghadapi masalah dan tekanan dalam hidupnya. Hal ini senada dengan pengertian resiliensi yang sebelumnya telah dipaparkan. Maka dari itu munculah pertanyaan, apakah spiritualitas memiliki peran dalam membentuk resilensi? apakah memang benar pelatihan spiritualitas pada residen narkoba saat menjalani rehabilitasi mampu meningkatkan resilensi mereka?.

Sejauh pengamatan penulis, studi yang dilakukan oleh Mahesti pertiwi pada tahun 2011 dengan judul "Dimensi Religiusitas Dan Resiliensi Pada Residen Narkoba Di BNN LIDO “. Mahesti pertiwi mengkaji bagaimana dimensi-dimensi religiusitas diantaranya religiusitas general religiosity, religiusitas social religiosity, religiusitas involved God, religiusitas forgiveness, religiusitas God as judge, religiusitas unvengefulness, religiusitas thankfulness dapat mempengaruhi tingkat resilensi residen narkoba. Berdasarkan hasil penelitian dapat disimpulkan bahwa terdapat pengaruh yang signifikan dimensi religiusitas terhadap resiliensi residen narkobadi BNN Lido.

Selain Mahesti, Abdul Basit memaparkan hasil penelitian dengan Judul "Pengaruh Pelatihan Spiritual Untuk Meningkatkan Resiliensi pada Residen Penyalahguna Narkoba di Panti Sosial Pamardi Putra “. Dalam penelitianya Abdul basit mengkaji bagaimana pengaruh pelatihan spiritual untuk meningkatkan resiliensi pada residen penyalahguna narkoba di panti sosial Pamardi Putra "Sehat Mandiri" Yogyakarta. Subjek penelian ini adalah residen penyalahguna narkoba yang sedang menjalankan program rehabilitasi pada tahap aftercare di panti sosial Pamardi Putra "Sehat Mandiri" Yogyakarta yang berjumlah 6 orang. Subjek dalam penelitian ini mendapatkan pelatihan spiritual yang disusun berdasarkan aspek-aspek spiritual, yaitu makna hidup, emosi positif, pengalaman spiritual, dan ritual. Pelatihan ini terdiri dari empat sesi dan diberikan selama dua hari. Dari hasil penelitian ini adalah tidak ada pengaruh yang signifikan pelatihan spiritual untuk meningkatkan resiliensi residen penyalahguna narkoba sesudah mengikuti pelatihan spiritual. 
Residen narkoba merupakan mantan pecandu narkoba yang telah menjalani proses rehabilitasi. Masalah yang sesungguhnya pada residen narkoba adalah kembalinya pada kehidupan bermasyarakat dimana akan terjadi masalah seperti relapse, stigma negatif dari masyarakat, dan lain sebagainya. Oleh karena itu, masalah tersebut akan membawa residen narkoba dalam keadaan mental yang tertekan. Dalam ilmu psikologi, individu yang mampu menghadapi tekanan dalam hidupnya dan mengubahnya menjadi positif disebut Resiliensi. Namun, Reivich dan Shatte menyebutkan bahwa hampir semua orang tidak dapat memenuhi aspek-aspek resiliensi dikarenakan tingkat kesulitanya. Selain kebutuhan psikologis manusia harus memenuhi kebutuhan non-materil yang disebut sebagai spiritualitas. Individu dengan spiritualitas yang baik dapat menghadapi tekanan dan permasalahan karena dengan spiritualitas yang dimilikinya akan mengaitkan setiap pengalaman hidup dengan sesuatu yang transenden agar individu mampu memaknai setiap pengalaman dalam hidupnya meskipun dalam keadaan tertekan. Pondok Pesantren Inabah XX dijadikan setting penelitian karena memiliki metode rehabilitasi narkoba berbasis spiritual melalui terapi ibadah.

Pemaparan di atas menimbulkan pertanyaan tentang gambaran spiritualitas dan resiliensi pada residen narkoba di Pondok Pesantren Inabah XX. Selain itu, sejauh mana peran spiritualitas dapat meningkatkan resiliensi pada residen narkoba. Penelitian ini bertujuan untuk mendeskripsikan peran spiritualitas dalam meningkatkan resiliensi pada residen narkoba di Pondok Pesantren Inabah XX. Adapun deskripsi yang disajikan antara lain gambaran spiritualitas, gambaran resiliensi, dan peran spiritualitas dalam meningkatkan resiliensi.

\footnotetext{
${ }^{8}$ Elkins, D.N., Toward a Humanistic Phenomenological Spirituality: Definition, Description, and Measurement', Humanistic Psychology. (1998) 18.
}

Mengenai spiritualitas, penulis merujuk pada teori Elkins. Terdapat 9 dimensi dari spiritualitas berdasarkan studi literatur Elkins yaitu : ${ }^{8}$

\section{Kesucian Hidup}

Seseorang dengan spiritualitas yang tinggi mampu menyucikan jiwanya agar kehidupanya tentram dan bahagia, jika seseorang selalu berusaha dalam menyucikan jiwa maka dia akan memperoleh suatu kekhidmatan dan kekhusyukan saat berhubungan dengan realitas transenden seperti cahaya matahari di pagi hari saat menyinari bumi. Orang dengan spiritualitas yang tinggi memahami bahwa untuk berhubungan dengan realitas transenden diperlukan jiwa yang suci, jika keseharianya dikotori oleh prilaku yang buruk maka realitas transenden tidak akan masuk kedalam diri seseorang.

\section{Altruisme}

Seseorang dengan spiritualitas yang tinggi memahami bahwa seluruh manusia dimuka bumi ini bersaudara dan merasa empati dengan penderitaan orang lain. Dia memiliki perasaan kuat mengenai keadilan sosial dan komitmen terhadap cinta dan perilaku altrusitik.

\section{Idealisme}

Seseorang dengan spiritualitas yang tinggi memiliki keyakinan yang kuat atas kekuatan transenden diluar kehidupan matrealitsik, sehingga potensi kehidupanya dimanfaatkan untuk mendekatkan diri pada sesuatu yang transenden itu. ${ }^{9}$

\section{Makna dan tujuan hidup}

Orang spiritual akan memiliki makna hidup dan tujuan hidup yang timbul dari keyakinan bahwa hidup itu penuh makna

\footnotetext{
${ }^{9}$ Elkins, D.N., Toward a Humanistic Phenomenological Spirituality: Definition, Description, and Measurement', Humanistic Psychology. (1998) 19.
} 
dan orang akan memiliki eksistensi jika memiliki tujuan hidup. Secara aktual, makna dan tujuan hidup setiap orang berbeda-beda atau bervariasi, tetapi secara umum mereka mampu mengisi "exixtential vacum" dengan authentic sense bahwa hidup itu penuh makna dan tujuan.

\section{Transenden/Keyakinan}

Seseorang dengan spiritualitas yang tinggi mempercayai eksitensi transenden dibalik kehidupan ini. Dimensi transenden adalah eksistensi alamiah dari kesadaran diri dari wilayah ketidaksadaran atau greater self. Orang spiritual memiliki pengalaman transenden atau dalam istilah Maslow "peak experience". Individu melihat apa yang dilihat tidak hanya apa yang terlihat secara kasat mata, tetapi juga dunia yang tidak dapat terlihat.

\section{Kesadaran akan adanya penderitaan}

Seseorang dengan spiritualitas yang tinggi memiliki kesadaran akan adanya penderitaan dan kematian, dengan demikian mereka meyakini bahwa kehidupan di muka bumi ini hanyalah sebuah mimpi yang panjang, maka dari itu saat kesadaran ini telah berhasil diaktifkan maka kita akan tetap mampu mengambil hikmah yang positif saat menghadapi musibah. ${ }^{10}$

\section{Misi Hidup}

Seseorang dengan spiritualitas yang tinggi merasa bahwa dirinya harus bertanggung jawab terhadap hidupnya. Hal ini berkaitan erat tentang penemuan jati diri tentang "siapa aku?", "untuk apa aku hidup?"

\section{Kepuasan spiritual}

\footnotetext{
${ }^{10}$ Elkins, D.N., Toward a Humanistic
}

Phenomenological Spirituality: Definition, Description, and Measurement', Humanistic Psychology. (1998), 20. ${ }^{11}$ Elkins, D.N , Toward a Humanistic Phenomenological Spirituality: Definition, Description,
Seseorang degan spiritualitas yang tinggi tidak akan menemukan kepuasan dalam materi tetapi kepuasan diperoleh dari spiritual, jika spiritualitasnya baik maka kehidupan dunianya pun akan baik.

\section{Hasil dari Spiritualitas}

Spiritualitas yang dimiliki oleh seseorang akan mewarnai kehidupannya, dengan spiritualitas yang baik seseorang akan mampu menjaga hubungan baik dengan Tuhanya, sesamanya, dan juga alam semesta. ${ }^{11}$

Sementara pembahasan resiliensi, penulis merujuk pada teori H. Grotberg dan Reivich \& Shatte. Menurut grotberg, Ada beberapa faktor yang dapat menunjukan resiliensi individu.Adapun faktor-faktor yang mempengaruhi resiliensi individu menurut Grotberg yaitu:

\section{I Have}

I Have merupakan dukungan dan sumber eksternal yang meningkatkan resiliensi. Desmita menyebutkan faktor tersebut merupakan karakteristik resiliensi yang bersumber dari pemaknaan individu terhadap besarnya dukungan dan sumber daya yang diberikan lingkungan sosial. ${ }^{12}$ Individu membutuhkan dukungan dari lingkunagn sekitarnya ketika ia menghadapi suatu permasalahan dalam hidupnya, hal ini berfungsi sebagai kekuatan eksternal. Grotberg juga berpendapat bahwa individu yang mempunyai hubungan yang dapat dipercaya akan membuat individu merasa nyaman dan aman. ${ }^{13}$ Ketika seseorang menghadapi permasalahan yang cukup

and Measurement', Humanistic Psychology. (1998), 20

${ }^{12}$ Desmita , Psikologi Perkembangan Peserta Didik, 204.

${ }^{13}$ Grotberg Henderson, Tapping Your Inner Strenght (Canada: New Harbinger Publications, 1999), 73. 
rumit maka lingkungan sekitar termasuk keluarga dapat menjadi kekuatan individu dalam menghadapi permasalahan tersebut. Dukungan dan kepercayaan amat sangatlah penting bagi seseorang, bila seseorang merasa sudah dipercayai oleh lingkungan sekitar maka individu tersebut akan berusaha keras untuk menjaga dan membuktikan pada lingkunganya agar tidak mengecewakan kepercayaan yang telah diberikan.

\section{I Am}

I Am merupakan kekuatan yang bersumber dari diri sendiri. Kekuatan ini merupakan aspek yang penting pada individu yang resilien. Grotberg menyebutkan bahwa faktor ini meliputi perasaan, sikap, dan keyakinan di dalam diri individu. Individu yang resilien pada sumber ini yaitu individu yang: ${ }^{14}$

\section{I Can}

Desmita menyatakan bahwa I Can merupakan kemampuan sosial dan interpersonal individu. Faktor ini merupakan karakteristik resiliensi yang bersumber dari apa saja yang dapat dilakukan individu sehubungan dengan keterampilan sosial dan interpersonal. ${ }^{15}$ Sependapat dengan hal tersebut, Grotberg berpendapat bahwa individu belajar kemampuan ini dengan berinteraksi dengan orang lain. Individu yang resilien di sumber ini yaitu individu yang: ${ }^{16}$

Sementara menurut Reivich \& Shatte, resiliensi mencakup tujuh aspek yaitu regulasi emosi, pengendalian implus, optimis, analisis penyebab masalah, empati, efikasi diri, dan reaching out. ${ }^{17}$

\footnotetext{
${ }^{14}$ Grotberg , A Guide to Promoting Resilience in Children: Strenghthening The Human Spirit, 16 ${ }^{15}$ Desmita, Psikologi Perkembangan Peserta Didik , 204.

${ }^{16}$ Grotberg, A Guide to Promoting Resilience in Children: Strenghthening The Human Spirit, 17 .

${ }^{17}$ A Reivich, K \& Shatte, The Resilience Factor: 7 Keys to Finding Your Inner Strength and Overcoming Life's Hurdles (New York: Broadway Books, 2002), 33.
}

\section{Regulasi emosi}

Reivich \& Shatte mendefinisikan regulasi emosi merupakan kemampuan tetap tenang dalam kondisi dibawah tekanan. ${ }^{18}$ Seseorang yang dapat mengontrol emosinya maka ia akan terhindar dari gangguan fisik seperti darah tinggi. Karena dalam bidang kesehatan, seseorang yang cepat marah dan mudah meluap emosinya akan mengidap penyakit tersebut. Sedangkan dampak secara psikis adalah timbul gangguan seperti timbulnya, stress, rasa iri dengki, tidak mau menerima masukan dari orang lain, dan sifat egonya lebih tinggi. Selain itu, seseorang yang tidak mampu mengontrol emosi akan dijauhi oleh lingkungan sosial.

\section{Pengendalian implus}

Pengendalian implus merupakan kemampuan individu dalam mengendalikan keinginan, dorongan, dan tekanan yang muncul dari dalam diri seseorang. ${ }^{19}$ Yang dimaksud dengan keinginan dan dorongan tersebut adalah sesuatu yang bersifat negatif. Terkadang seseorang menginginkan sesuatu dengan tujuan yang tidak baik dan bersifat destruktif, sehingga ia tidak akan berpikir jangka panjang dan memikirkan konsekuensi yang akan terjadi pada dirinya dan juga lingkunganya. Seseorang yang mampu menahan keinginan-keinginan yang negatif mampu melati sikap sabar.Selain itu akal sehatnya mampu dilatih untuk berpikir

\footnotetext{
${ }^{18}$ Reivich K \& Shatte A, The Resilience Factor: 7 Keys to Finding Your Inner Strength and Overcoming Life's Hurdles , 36.

${ }^{19}$ Reivich, K \& Shatte, A. The Resilience Factor: 7 Keys to Finding Your Inner Strength and Overcoming Life's Hurdles , 39.
} 
jangka panjangnya. Hubungan antara regulasi emosi dan implus control sangatlah besar. Jika seseorang mampu menahan keinginan-keinginan negatifnya maka secara langsung dia mampu mengendalikan emosinya dengan baik.

\section{Optimis}

Reivich \& Shattemenyatakan bahwa individu yang resilien adalah individu yang optimis.Individu yang resilien adalah mereka yang mampu melakukan segala sesuatu denga berpikir positif dan percaya diri, karena dalam aspek optimis terdapat kedua hal tersebut. Selain itu mereka juga mempercayai bahwa kehidupan dapat berubah menjadi lebih baik dimasa depan, sehingga mereka menjadikan masalalu sebagai pelajaran yang berharga. Seseorang yang memiliki sifat optimis akan mampu menyelesaikan masalah dalam hidupnya. Baginya masalah merupakan proses pematangan diri agar menjadi lebih kuat. ${ }^{20}$

4. Analisis penyebab masalah

Analisis penyebab masalah merupakan kemampuan individu dalam mengidentifikasi penyebab masalah secara akurat. $^{21}$ Hal ini amat penting dalam membentuk resilien seseorang.Jika individu tidak mampu menganalisa akar dan penyebab masalah secara tepat maka dirinya akan melakukan kesalahan yang sama.Seseorang yang mampu menganalisa masalahnya secara otomatis mampu mengintrospeksi dirinya.Analisis penyebab masalah berhubungan dengan mind-set (pola pikir) seseorang.

\footnotetext{
${ }^{20}$ Reivich, K \& Shatte, A, The Resilience Factor: 7 Keys to Finding Your Inner Strength and Overcoming Life's Hurdles, 40.

${ }^{21}$ Reivich, K \& Shatte, A, The Resilience Factor: 7 Keys to Finding Your Inner Strength and Overcoming Life's Hurdles, 41.
}

Individu yang terlatih dalam menganalisa masalahnya, maka ia akan mampu mengambil setiap pelajaran dari berbagai masalah tersebut, sehingga kualitas hidupnya akan meningkat.

5. Empati

Empati merupakan kemampuan individu dalam menyelami perasaan yang sedang dialami oleh orang lain baik keadaan fisik maupun mentalnya. Dengan sikap empati maka seseorang mampu menciptakan hubungan sosial dan emosional yang baik dengan lingkunganya. Seseorang dengan sikap empati yang tinggi akan memberikan kenyamanan bagi orangorang sekitarnya. Empati sangat erat kaitanya dengan kepekaan sosial. Individu yang resilien yaitu individu yang mampu untuk memahami perasaan dan pikiran orang lain. ${ }^{22}$

\section{Efikasi diri}

Reivich \& Shatte mendefinisikan efikasi diri sebagai keyakinan pada kemampuan diri sendiri untuk menghadapi dan memecahkan masalah dengan efektif. ${ }^{23}$ Efikasi diri sangat erat kaitanya dengan analisis masalah, sebelum memikirkan cara yang efektif dalam memecahkan masalah maka seseorang harus memikirkan penyebab akar permasalahan yang terjadi sebelumnya. Jika akar permaslahan yang dihadapi sudah teridentifikasi maka seseorang akan mampu memikirkan bagaimana cara efektif dalam menyelesaikan masalahnya tersebut. Efikasi diri merupakan teknik dalam membaca diri dan segala potensi-potensi yang dimiliki,

\footnotetext{
${ }^{22}$ Reivich, K \& Shatte, A. The Resilience Factor: 7 Keys to Finding Your Inner Strength and Overcoming Life's Hurdles, 44.

${ }^{23}$ Reivich, K \& Shatte, The Resilience Factor: 7 Keys to Finding Your Inner Strength and Overcoming Life's Hurdles A, 45.
} 
sehingga ia akan mampu menutupi kekuranganya dengan potensi-potensi tersebut.

\section{Reaching out}

Reaching out merupakan kemampuan individu dalam mengoptimalkan aspekaspek positif yang ada dalam dirinya. Menurut Reivich \& Shatte individu yang selalu meningkatkan aspek positif dalam dirinya akan lebih mudah dalam mengatasi permasalahan hidup dan berperan dalam meningkatkan kemampuan interpersonal serta pengendalian emosi. ${ }^{24}$

\section{B. HASIL DAN PEMBAHASAN}

Dari hasil penelitian penulis di Pondok Pesantren Inabah XX melalui wawancara dan observasi pada residen narkoba. Adapun aspek yang diteliti adalah gambaran spiritualitas residen narkoba sebelum masuk inabah dan setelah masuk inabah, aspek dari spiritualitas yang diteliti merujuk pada aspek yang membentuk spiritualitas menurut Elkins (1998) yaitu aspek kesucian hidup, alturisme, idealisme, makna dan tujuan hidup, keyakinan transenden, kesadaran akan adanya penderitaan, misi hidup, kepuasan spiritual, dan hasil dari spiritual. Hal yang sama dilakukan untuk meneliti gambaran resiliensi pada residen narkoba. Adapun aspek resiliensi yang diteliti merujuk pada teori Reivich dan Shatte (2002) yaitu regulasi emosi, implus kontrol (pengendalian keinginan), optimis, analisis penyebab masalah, empati, efikasi diri, dan reaching out (aspek positif). Selain itu penulis juga merujuk pada faktor pembentuk resiliensi menurut Grotberg (1999) yaitu faktor I have, I am, dan I can. Berikut adalah hasil penelitian dari 5 orang residen narkoba.

Menurut

hasil

penelitian, keterhubungan antara peran spiritualitas dan resiliensi terletak pada :

\section{Kesucian Hidup Dapat Meningkatkan Regulasi Emosi Dan Implus Control.}

Kesucian hidup merupakan aspek terpenting dalam spiritualitas, seseorang yang selalu berusaha menyucikan hidupnya akan merasa tenang dan khidmat. Untuk mencapai kesucian hidup, seseorang diwajibkan untuk membersihkan kotoran terlebih dahulu. Kotoran yang dimaksud adalah akhlak yang bersifat destruktif. Karena kesucian tidak akan pernah hadir pada individu yang memiliki akhlak yang buruk. Akhlak yang buruk dapat mendorong seseorang dalam melakukan keinginankeinginan negatif, salah satunya adalah menyalahgunakan narkoba. Maka dari itu seseorang yang terjerat kasus narkoba akan melahirkan akhlak yang bersifat destruktif seperti mudah emosi dan melakukan segala cara untuk mendapatkan barang haram tersebut. Kharisudin Aqib (2005:147) menyebutkan bahwa seorang pecandu narkoba akan melakukan hal apapun tidak peduli benar atau salah, baik atau buruk, halal atau haram.

Dari pemaparan diatas dapat disimpukan bahwa kesucian hidup dapat mempengaruhi tingkat regulasi emosi dan implus kontrol, maka butuh proses untuk menyucikan hidup dari kotoran yang bersifat duniawi. Proses tersebut menurut Kharisudin Aqib disebut dengan Tazkiyatun Nafs. ${ }^{25}$ Tazikiyatun nafs merupakan proses

\footnotetext{
${ }^{25}$ Kharisudin aqib, Inabah Jalan Kembali Dari Narkoba, Stres Dan Kesunyian, 17.

${ }^{24}$ Reivich, K \& Shatte, A, The Resilience Factor: 7 Keys to Finding Your Inner Strength and Overcoming Life's
} Hurdles, 46. 
penyucian jiwa melalui metode ibadah, hal ini di yakini dapat membersihkan keinginan negatif (hawa nafsu) dan gangguan emosi pada pecandu narkoba.

Berdasarkan hasil penelitian, residen narkoba yang menjalani proses rehabilitasi di Pondok Pesantren Inabah XX mengalami perkembangan yang pesat dalam mengendalikan emosi dan keinginan negatif. Hal tersebut ditandai dengan ketenangan jiwa dan kesabaran saat melaksanakan ibadah yang begitu banyak serta berkurang atau bahkan hilangnya keinginan untuk kabur dari pesanteren inabah dan kembali mengkonsumsi narkoba.

\section{Alturisme Dapat \\ Meningkatkan Empati , Aspek I Have, Dan Aspek I Am}

Alturisme adalah hadirnya rasa persaudaraan dan keikut sertaan individu dalam merasakan penderitaan orang lain. Dari pengertian tersebut terdapat aspek Empati sebagai salah satu syarat seseorang dalam meningkatkan resiliensi. Menurut Reivich dan Shatte (2002:44) individu yang resilien adalah individu yang mempu untuk memahami perasaan dan pikiran orang lain. Hal itu senada dengan pengertian alturisme dalam dimensi spiritualitas. Sementara rasa persaudaraan akan membentuk hubungan yang harmonis serta dukungan positif antara individu dengan lingkunganya. Hubungan yang harmonis serta dukungan dari lingkungan akan menimbulkan hubungan kepercayaan yang disebut dengan I Have. Dari hubungan kepercayaan tersebut akan timbul perasaan, sikap, dan keyakinan dalam diri individu yang disebut sebagai I Have (Grotberg 1995:16).

Berdasarkan hasil penelitian, keadaan alturisme pecandu narkoba sebelum menjalani proses rehabilitasi Di Inabah sangatlah rendah. Terbukti hampir seluruh residen narkoba tidak pernah mengikuti kemauan orang tua dan selalu membangkang ketika dinasehati soal penggunaan narkoba tanpa memperdulikan perasaan orang tua. Alturisme yang rendah berdampak pada rasa empati yang begitu rendah terhadap orangtuanya, merasa tidak memiliki tempat untuk menyelesaikan masalah, dan merasa tidak disayangi oleh orangtuanya. Namun stelah residen menjalani proses rehabilitasi. Sikap alturisme muncul dari lingkungan di Inabah sebagai proses terbentuknya rasa persaudaraan antar residen narkoba. Yang kemudian saling mengingatkan dalam kebaikan dan merubah presepsi negatif tentang orangtua.

3. Idealisme Dapat Meningkatkan Implus Control Dan Optimis

Idealisme dalam aspek spiritual sangat erat kaitanya dengan keyakinan terhadap realitas transenden/Tuhan. Seseorang yang meyakini keberadaan dan kekuasaan Tuhan akan senantiasa melakukan apa yang diperintahkan-Nya dan menjauhi segala dilarang-Nya, dengan demikian seseorang akan melindungi dirinya dari hukum Tuhan dengan ketundukan kepada-Nya. ${ }^{26}$ Dengan idealisme yang kuat, seorang pecandu narkoba akan menahan keinginan negatif (implus control) seperti kembali menggunakan narkoba dan meyakini bahwa Tuhan akan memberikan jalan yang terbaik untuknya (optimis).

Berdasarkan hasil penelitian, idealisme residen narkoba terhadap Tuhan hanya sebatas pada meyakini, tanpa melaksanakan perintar dari-Nya. Dampak dari idealisme

\footnotetext{
${ }^{26}$ Drs. Tamami, Psikologi Tasawuf, 200.
} 
yang rendah akhirnya mendorong keinginan pecandu narkoba untuk tetap menggunakan narkoba tanpa memperdulikan dampak negatifnya, selain itu dampak dari idealisme yang rendah adalah timbulnya rasa pesimis dalam menghadapi masalah. Sementara itu, berdasarkan hasil penelitian setelah residen narkoba menjalani proses rehabilitas ratarata mampu meningkatkan idealisme. Dengan idealisme yang kuat maka residen narkoba akan meninggalkan keinginankeinginan negatifnya terutama dalam mengkonsumsi narkoba serta mempercayai bahwa Tuhan akan menolong hamba-Nya yang mengalami kesulitan

\section{Makna Dan Tujuan Hidup Dapat Meningkatkan Analisa Masalah Dan Efikasi Diri. \\ Makna dan tujuan hidup merupakan} bagian eksitensi manusia dalam memperoleh kebahagiaan yang hakiki. Seseorang dengan makna dan tujuan hidup akan mengambil hikmah dari setiap pengalaman yang terjadi dalam kehidupanya. Sehingga hidupnya tidak akan pernah hampa meski menghadapi berbagai macam masalah, sebab individu yang mampu memaknai dan mengarahkan hidupnya akan mampu membaca masalah dan mencari jalan keluar. Dalam resiliensi hal itu disebut dengan analisa pemecahan masalah dan efikasi diri.

Salah satu faktor pecandu narkoba mengalami kehampaan hidup dan memakai narkoba karena ketidakmampuan menghadapi masalah. ${ }^{27}$ Selanjutnya pipih sopiah menyebutkan bahwa menjadi suatu keharusan bagi mantan pecandu narkoba dalam menghadapi masalah dan mencari jalan keluarnya.
Berdasarkan hasil penelitian, residen narkoba yang telah menjalani proses rehabilitasi mampu memaknai dan mengarahkan hidupnya lebih baik lagi dengan pengalaman dan hikmah selama berada di Inabah. Hal itu terbukti ketika para residen mampu memaknai dan belajar dari kesalahan di masa lalunya. Sehingga ratarata dari residen narkoba merasa yakin telah menemukan jalan keluar dari permasalahan yang ada.

\section{Transenden Dapat}

Meningkatkan Aspek Reaching Out

Transenden merupakan eksitensi alamiah dari kesadaran diri. Seseorang yang memahami realitas transenden akan memahami aspek-aspek positif yang tersembunyi dalam diri seseorang. Menurut Elkins (1998) dengan keadaan transenden, individu melihat apa yang dilihat tidak hanya apa yang terlihat secara kasat mata. Maksudnya seseorang mampu memahami makna tersembunyi dibalik kejadian positif dalam diri individu. memahami setiap kejadian dan memanfaatkan aspek positif merupakan kemampuan resiliensi yang disebut dengan reaching out.

Berdasarkan hasil penelitian sebelum residen narkoba menjalani proses rehabilitasi, rata-rata residen narkoba memahami kejadian transenden berdasarkan efek dari narkoba yang memabukan, sehingga individu merasakan kebahagiaan dan ketentraman dari mabuknya tanpa mengetahui dampak negatif dari narkoba, dengan kata lain seorang pecandu narkoba mengubur aspek positif dalam dirinya ketika mencapai suatu ketenangan. Keadaan transenden rata-rata dialami oleh residen narkoba yang sudah menjalani proses

\footnotetext{
${ }^{27}$ Pipih Sopiah, Stop Narkoba Dari Segala Penjuru, 46.
} 
rehabilitasi. Seluruh residen narkoba menyatakan bahwa dengan melaksanakan amalan ibadah secara konsisten dapat menimbulkan ketenangan dan kesadaran (transenden), hasilnya akan muncul aspek positif seperti ikhlas, sabar, tentram dan bahagia .

\section{Kesadaran Akan Adanya Penderitaan Dapat Meningkatkan Implus Control}

Kesadaran akan adanya penderitaan merupakan kesadaran yang didasari atas kebahagiaan akhirat sebagai puncak dari kebahagiaan. Pernyataan tersebut sesuai dengan definisi zuhud. Zuhud adalah sikap menjauhi dunia dan isolasi terhadap keramaian duniawi. ${ }^{28}$ Yang dimaksud dengan menjauhi dunia adalah menjauhi keinginan-keinginan negatif berdasarkan hawa nafsu semata (Implus Control). Maka, seseorang yang mampu menyadari akan adanya penderitaan di dunia mampu mengendalikan keinginan negatif karena kesadaran akan nilai kebahagiaan matrealistik hanya sementara dan apabila terus-menerus dikejar hanya menimbulkan penderitaan.

Berdasarkan hasil penelitian, sebelum residen narkoba menjalani proses rehabilitasi menganggap bahwa narkoba merupakan penyelamat dari masalah bahkan menyebutkan bahwa narkoba sudah menjadi kebutuhan hidup meskipun mereka menyadari dampak negatifnya. Pecandu narkoba tidak mampu mengendalikan dorongan-dorongan yang kuat dalam prilaku destruktif seperti mencuri, menipu, dan lain sebagainya demi mendapatkan barang haram tersebut meskipun terikat dengan hukum. Setelah residen narkoba menjalani proses rehabilitasi, timbul kesadaran akan bahaya narkoba dan menyadari bahwa narkoba merupakan perenggut kebahagiaan hidup yang harus dimusuhi oleh seluruh manusia.

\section{Misi Hidup Dapat} Meningkatkan Aspek Reaching Out

Menurut Elkins (1998) Misi hidup merupakan adanya tanggung jawab dan motivasi dalam merencanakan hidup. Tanpa perencanaan hidup seseorang tidak mampu mengoptimalkan potensi yang ada dalam dirinya. Dalam diri seseorang terdapat potensi positif, jika potensi itu dimanfaatkan dengan optimal maka disbeut reaching out (dalam bahasa resiliensi).

Berdasarkan hasil penelitian, rata-rata residen narkoba sebelum menjalani proses rehabilitasi mengalami kebingungan dalam merencanakan hidupnya. Dampaknya adalah perasaan bingung dalam memilih jalan hidup dan memilih jalan pintas yang keliru dengan menggunakan narkoba. Setelah residen narkoba menjalani proses rehabilitasi. Semua residen narkoba memiliki misi hidup dengan merencanakan berbagai macam hal seperti bekerja dan sekolah di lingkungan baru hingga menggunakan potensi harta untuk membangun tempat rehabilitasi seperti Pondok Pesantren Inabah XX.

\section{Kepuasan Spiritual Dapat Meningkatkan Regulasi Emosi Dan Implus Control}

Menurut Elkins (1998) Seseorang dengan spiritualitas yang tinggi tidak akan menemukan kepuasan dalam materi tetapi kepuasan diperoleh dari pengalaman spiritual. Spiritualitas yang dimaksud merupakan hasil dari pengamalan ibadah yang dilakukan oleh para residen narkoba. Setelah residen narkoba mampu

\footnotetext{
${ }^{28}$ Drs. Tamami, Psikologi Tasawuf, 135.
} 
menyucikan hidupnya dengan konsiten beribadah maka ia akan menemukan kepuasan spiritual yang mempengaruhi pengendalian emosi dan keinginan negatif.

Berdasarkan hasil penelitian, rata-rata residen narkoba mengalami kepuasan batin setelah melakukan ibadah dengan konsiten. Bahkan dapat menyembuhkan penyakit yang disebabkan zat beracun dari narkoba. Selain itu, ibadah yang dilakukan sebanyak itu membentuk kepribadian sabar dan ikhlas sehingga manfaat psikologisnya berupa regulasi emosi dan implus control yang baik.

9. Hasil Dari Spiritualitas Dapat Meningkatkan Aspek I Have, I Am, Dan I Can

Hasil dari spiritualitas merupakan perasaan ultimate dalam menjalani hubungan dengan realitas transenden. Seseorang dengan spiritualitas yang tinggi dapat menjalani hubungan dengan sesama manusia, alam, maupun Tuhan. Dalam menjalani hubungan dengan Tuhan, ibadah merupakan salah satu faktor yang penting setelah membersihkan hati. Dengan ibadah, maka seseorang akan dekat dengan Tuhanya.

Berdasarkan hasil penelitian, manfaat dari konsitensi ibadah di pondok pesantren inabah adalah menghadirkan rasa bersyukur dan cinta kepada Allah. Hal tersebut senada dengan pengertian Mahabbah. Mahabbah adalah usaha mewujudkan rasa cinta dan kasih sayang yang ditujukan kepada Allah Ta'ala. ${ }^{29}$ Dengan cinta terhadap Allah, maka mencintai karena Allah merupakan keharusan bagi yang dicintai-Nya. Allah menciptakan alam semesta dan isinya berdasarkan atas kasih sayang-Nya. Dari pemaparan diatas, rata-rata residen narkoba merasakan bahwa Allah menyayangi dirinya. Sehingga Allah merupakan tempat terbaik dalam mengadukan keluh kesah melalui dzikir (I Have), bersyukur dan berakhlak baik terhadap sesama (IAm), dan mengajarkan kebaikan yang didapatkan kepada orang lain yang membutuhkan (I Can).

\section{C.SIMPULAN}

Berdasarkan hasil penelitian dan pembahasan, dapat disimpulkan bahwa gambaran spiritualitas residen narkoba Di Pondok Pesantren Inabah XX mengalami Perkembangan yang pesat dari sebelumnya, diantaranya: Meningkatnya kesucian hidup yang ditandai dengan konsistensi ibadah, Alturisme yang ditandai dengan hubungan persaudaraan yang erat antar residen narkoba, Sikap idealisme yang ditandai dengan kepercayaan dan komitmen terhadap Tuhan, Makna dan tujuan hidup yang ditandai dengan usaha yang kuat untuk berubah melalui ibadah, Keadaan transenden yang ditandai dengan kebahagiaan dan kenikmatan dalam beribadah, Meningkatnya kesadaran akan adanya penderitaan yang ditandai dengan penolakan terhadap narkoba, Memiliki misi hidup yang ditandai dengan perencanaan hidup yang matang, Mencapai kepuasan spiritual yang ditandai dengan perubahan perilaku yang lebih positif dari proses ibadah, dan Merasakan hasil spiritualitas yang ditandai dengan kecintaan terhadap Tuhan.

Begitupula dengan gambaran resiliensi, secara garis besar rata-rata residen mengalami peningkatan resiliensi diantaranya adalah Regulasi emosi yang meningkat ditandai dengan sikap sabar dan ikhlas saat beradaptasi dengan lingkungan baru, Implus control yang ditandai dengan

${ }^{29}$ Drs. Tamami, Psikologi Tasawuf, 192. 
mengendalikan keinginan untuk memakai kembali narkoba, Sikap optimis yang ditandai dengan keyakinan dan usaha yang kuat untuk berubah, Tumbuhnya sikap empati yang ditandai dengan saling berbagi baik bersifat meteril maupun moril antar residen narkoba, Analisis penyebab masalah yang ditandai dengan rasa penyesalan akibat penyalahgunaan narkoba dan introspeksi diri , Efikasi diri yang ditandai dengan mencari jalan keluar agar tidak terjadi relapse (kekambuhan), Meningkatnya reaching out yang ditandai dengan kesadaran akan adanya aspek positif dalam diri melalui proses ibadah, Meningkatnya aspek I Have yang ditandai dengan hubungan kepercayaan antar residen narkoba, Meningkatnya aspek $I A m$ yang ditandai dengan kesadaran akan kasih sayang orangtua, Meningkatnya aspek I Can yang ditandai dengan kesiapan diri residen narkoba untuk berinteraksi kembali dengan masyarakat.

Berdasarkan hasil penelitian tentang "Peran Spiritualitas Dalam Meningkatkan Resiliensi Pada Residen Narkoba", ada keterkaitan antara dimensi spiritualitas dan aspek resiliensi diantaranya:

1. Kesucian hidup akan meningkatkan regulasi emosi dan implus control

2. Alturisme akan meningkatkan sikap empati, aspek I Have, dan aspek I Am

3. Idealisme akan meningkatkan implus control

4. Makna dan tujuan hidup akan meningkatkan kemampuan analisis masalah dan efikasi diri

5. Keadaan transenden akan memunculkan aspek reaching out

6. Kesadaran akan adanya penderitaan akan meningkatkan implus control

7. Memiliki misi hidup akan memunculkan aspek reaching out

8. Kepuasan spiritual akan memunculkan meningkatkan regulasi emosi dan implus control
9. hasil dari spiritualitas akan meningkatkan aspek I Have, I Am, dan I Can.

\section{DAFTAR PUSTAKA}

Aqib, D. K. (2005). INABAH "Jalan Kembali Dari Narkoba,Stres, \& Kesunyian Hati.” Surabaya: Pt. Bina Ilmu.

BNN. (2004). Pedoman Pencegahan Penyalahgunaan Narkoba Bagi Pemuda. Jakarta: Badan Narkotika Nasional Republik Indonesia.

BNN. (2006). Kamus Narkoba Istilah-Istilah Narkoba dan Bahaya Penyalahgunaannya. Jakarta: Badan Narkotika Nasional Republik Indonesia.

Desmita. (2011). Psikologi Perkembangan Peserta Didik. Bandung: Remaja Rosdakarya.

Elkins, D.N., Hedstrom, J., Hughes, L.L., Leaf, J.A., \& Saunders, C. (n.d.). Toward a Humanistic phenomenological spirituality: definition, description, and measurement. Humanistic Psychology.

Henderson, G. (1995). A Guide to Promoting Resilience in Children: Strenghthening The Human Spirit. Netherlands: The Bernard van Leer Foundation.

Henderson, G. (1999). Tapping Your Inner Strenght. Canada: New Harbinger Publications.

Idris, A. Y. \& F. (1989). TEORI PSIKOLOGI. Fakulti Pendidikan, Universiti Teknologi Malaysia, (1978).

Mardani, D. . (2008). Penyalahgunaan Narkoba ( Dalam prespektif hukum Islam dan Hukum Pidana Nasional). Jakarta: PT. Raja Grafindo Persada.

Patalima, H. (2015). Resiliensi anak usia dini. 
Bandung: Alfabeta.

Reivich, K \& Shatte, A. (2002). The Resilience

Factor: 7 Keys to Finding Your Inner Strength

and Overcoming Life's Hurdles. New York:

Broadway Books.

Sopiah, P. (2009). Stop Narkoba Dari Segala

Penjuru. Bandung: PT. Elisa Surya Dwitama.

Tamami, D. (2011). Psikologi Tasawuf. Bandung:

Pustaka Setia. 